\title{
Watershed Management for Mukhyamantri Jal Sawablamban Abhiyan by Remote Sensing and GIS Application in Panchayat Samiti Balesar Block, Distt. Jodhpur (Rajasthan)
}

\author{
${ }^{[1]}$ Vinod Kumar Gusaiwal, ${ }^{[2]}$ Pratibha Manohar, ${ }^{[3]}$ Suparn Pathak \\ Collage of Agriculture, \\ Sri Karan Narendra Agriculture University Jobner, Jaipur(Raj)
}

\begin{abstract}
Mukhyamantri Jal Swavlamban Abhiyan is run by the Chief Minister to conserve and harvest rain water and make villages self-reliant even during drought periods. The purpose of this mission on water conservation is to make villages self-sufficient in water use and thus provide a permanent solution to the demand of water besides ensuring storage and conservation of water. In this project, various hydrological components of the Balesar block have been studied with the help of satellite derived information and watershed management has been analyzed. To support the abhiyan through this project, we studied the status of water available through ground water, storage of runoff water and present as well as future water requirement through the data of year 2015. We have also plotted several maps that will help in selection of locations to create new watersheds for storage of runoff water.
\end{abstract}

Keywords: Watershed, Drainage, Remote sensing and Geographical information system

\section{A. Watershed:}

\section{INTRODUCTION}

A watershed can be defined as an area from which runoff resulting from participation flows past a single point into a stream, river, lake or an ocean. The term watershed, catchment area or drainage basin is used synonymously. The watershed boundary is called drainage divide. Rains received on opposite sides of drainage divide do not excess water with safe contribute runoff and reach to the adjoining area.

A watershed is a topographical delineated area that is drained by a stream system i.e. the total land area that is drainage to some point on stream on a river. It is a hydrological unit that has been described and used as a physical biological unit and also, on many occasions, as a social-economical political unit for planning and management of natural resources.

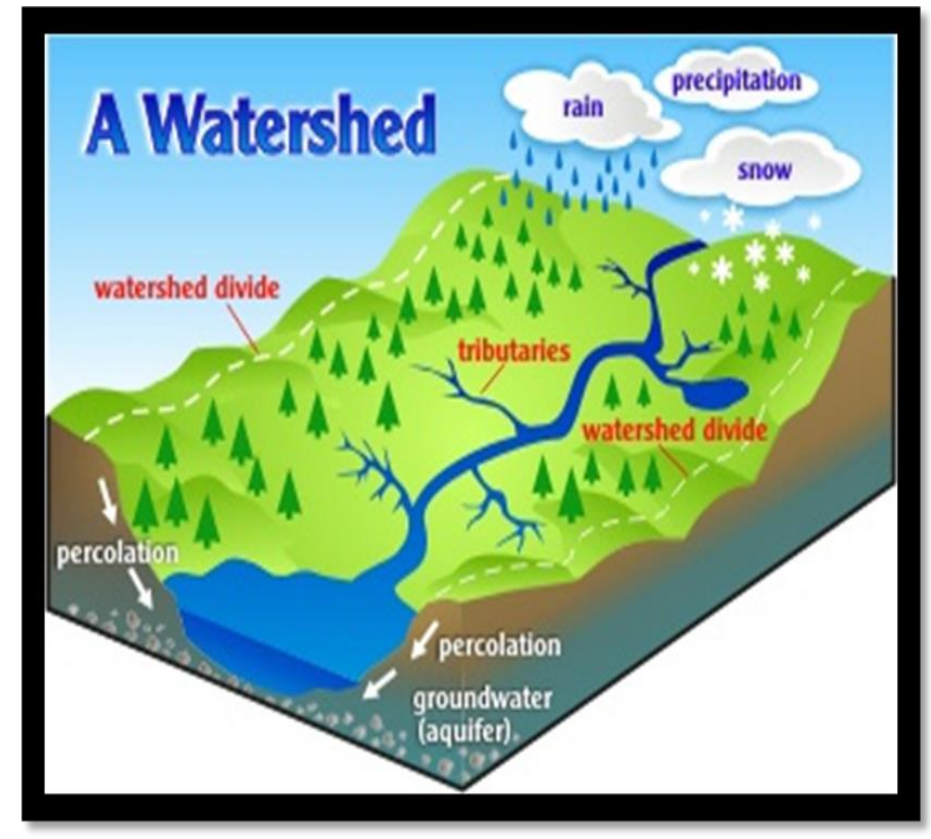

Figure 1: A Watershed Management System

\section{1) Runoff water:}

Runoff is that portion of total precipitation (rain and snow) that does not infiltrate into the soil but instead flows over the soil surface. When rain or snow falls onto the earth, it just doesn't assemble there it starts moving according to the laws of gravity. A portion of the precipitation seeps into the ground to replenish Earth's groundwater. Most of it flows downhill as runoff. Runoff is extremely important in that not only does it keep rivers and lakes full of water, but it also changes the landscape by the action of erosion.

\section{1) Factors affecting runoff water}

\section{1) Rainfall:}

Rainfall is essential parameter in the analysis of runoff and it contributes to overall calculation of watershed. Precipitation in arid and semi-arid zones results largely from convective cloud mechanisms producing storms typically of short duration, relatively high intensity and limited areal extent. However, low intensity frontal type rains are also experienced, usually in the winter season. 
The precipitation which occurs in the form of rainfall starts immediately as surface runoff depending upon rainfall intensity is greater than infiltration rate of soil then runoff starts immediately after rainfall. The high intensities of rainfall yield higher runoff. The duration of rainfall is directly related to the volume of runoff because infiltration rate of soil decreases with duration of rainfall. Therefore medium intensity rainfall even results in considerable amount of runoff if duration is longer. Runoff from a watershed also depends upon the distribution of rainfall.

\section{3) Soil texture:}

Soil texture refers to the relative proportion of clay, silt and sand. The risk of runoff and erosion is affected by small differences in texture. This is because texture influences the degree of percolation of water through the soil, and also the stability of soil.

Soils containing large proportions of sand have relatively large pores through which water can drain freely. These soils are at less risk of producing runoff. As the proportion of clay increases, the size of the pore space decreases. This restricts movement of water through the soil and increases the risk of runoff. Soils with low clay content are less cohesive and are inherently more unstable. These soils are at greater risk of erosion by water and wind.

\section{4) Soil structure:}

It refers to the arrangement of soil particles in the soil. Clay content, organic matter (and in some soils calcium and iron compounds) help to bind the soil together into structural units, aggregates. Well-structured soil allows the free movement of air and water through fissures (or cracks) between the structural units. Pores within the units also allow the movement of air and water. A soil with poor soil structure has a high risk of generating runoff. The risk of runoff is greatest when poor soil structure is near the soil surface. Soil structure deteriorates when structural units are deformed producing a dense single mass of soil (or large soil units). This occurs when pressure is applied to a wet and soft soil. Pressure squeezes the soil units together and reduces pore space within the units. A dry soil can withstand pressure without deforming soil structure.

\section{5) Slope:}

The slope in percent of the site contributes to runoff. The more the ground slopes, the more water will runoff from the site. Steep slopes can cause water to run off at a rapid rate. This is particularly the case where water percolation into the soil is slow (on naturally slowly draining soil or where there is poor soil structure or both). Highest risk fields are those greater than 35 percent. Fields with gentle slopes less than 0 percent are at lower risk to rapid runoff and erosion. But water can still run and gather momentum on gentle slopes, particularly where the slope is long and infiltration rate is slow. Where the ground is level, water will tend to pond.

\section{6) Land use:}

Land with a fine and smooth seedbed provides little surface storage capacity, and on sandy and light silt soil is at risk of becoming capped causing runoff and erosion. Fine, dry sandy tilts are vulnerable to wind erosion. The land use pattern is also the factors which contribute to runoff.

\section{7) Significance of watershed management:}

- Land utilization according to its capability.

- Maintenance of adequate vegetation covers for controlling soil erosion.

- In situ harvesting of rainwater.

- Drainage out of excess runoff water with safe velocity and storage for future use.

- Prevention of gully erosion and increasing ground water recharge.

\section{8) Role of GIS and remote sensing in watershed management:}

Understanding hydrological behaviors of a basin is necessary step towards the movement and distribution of water throughout the earth that address the management of water resources. One way is to acquire a better understanding to use remote sensing techniques. By using remote sensing data d erived hydrological responses, such as rainfall, runoff water and ground based observation such as drainage, slope, water body, river and different components of watershed comes under the hydrological behavior of a catchment area for the analysis of watershed and the calculation of rainfall.

In recent years, the advancement in satellite and computer technology along with different models and softwares has opened the opportunity to process and derive different hydrologic parameters on pixel basis. On the basis of these parameters we can calculate rainfall, runoff, drainage, contour and water body which leads to a proper quantification of watershed there by providing proper assessment of the hydrological behavior of a basin. Remote Sensing and GIS is considered as a vital tool for analyzing the watersheds.

\section{9) Study area:}

The selected study area was Panchayat Samiti Balesar block, Distt. Jodhpur (Rajasthan) for Watershed Management for Mukhaymantri Jal Sawablaban Abhiyan year 2015. In the project we studied four villages Belwa, Ketuhema, Kuiindha, Kuijodha of the three Gram panchayats Kuiidha, Belwa, Thripur. Geographically Balesar is located at longitude of $72^{\circ} 79^{\prime} 44^{\prime}$ ' East, latitude of $29^{\circ} 39^{\prime} 31^{\prime \prime}$ "North and at an elevation of 250 to 300 meters from mean sea level in Jodhpur district of Rajasthan. The total of area covered is 3840 ha. The index map of the study area is shown in Figure 1.2. 


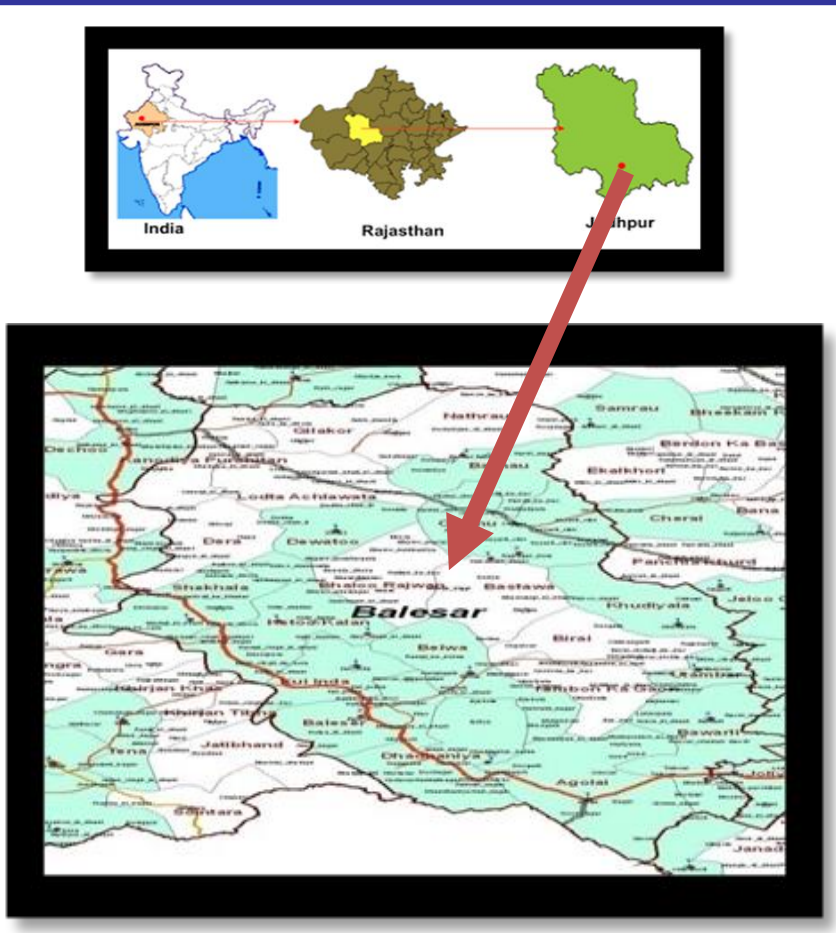

Figure 2: Study area: Balesar block

\subsection{0) Objectives of the study:}

a) To study the use of remote sensing approach to make the village a self-sufficient unit in drinking water through sustainable watershed area.

b) To study the use of land, the most valuable natural resource for production of food, fiber, fuel and many other essential goods, that are required to meet human and animal needs.

c) To study of Rainfall that has been recognized for long as the most important for agriculture, animal and human.

d) To study of drainage basins an extent or an area of land where surface water from rain, melting snow, or ice converges to a single point at a lower elevation.

\subsection{1) Scope of study:}

Mukhyamantri Jal Sawablamban Abhiyan is planned to help to identify the quantity of water available in different components of the watershed area. This knowledge will help in better management of water resources, runoff water, rainfall water and drainage and water deficit. Analysis of the effect of land use changes and climate changes on water availability, identification of recharge zones and suitable potential rainwater harvesting sites etc. Also the analysis carried out on land use and land cover, vegetation vigor, rainfall water, runoff water and water requirement for future will help in forming a sustainable development plan for the study area.

\section{III.MATERIALS AND METHODOLOGYS}

\section{1) Data used:}

Resource set LISS-III (linear imaging self scanner) data is used for this study along with other ancillary data and survey of Indian topography maps on 1:50,000 scale. Slope and drainage maps were prepared using SRTM (shuttle radar topography mission) data. The ground information on different land use and land cover (lulc) categories and activities under watershed development programme were collected by visiting the study area in the watershed along with satellite imagery. The field work was carried out along with concerned line department official during Kharif, Rabi and summer season of 2015. Satellite imageries, topographical maps and global position System (GPS) were utilized during ground truth collection. The field details were collection discussion with farmers as well as officers concerned in the watershed.

Land use and land cover classification were made into five different categories namely, crop land, fallow land, watershed land, water body and settlement. On screen digitization at 1:50,000 scales were done to carry out lulc categories for imagery data. Normalized difference vegetation index (NDVI) classification was done for extracting biomass index for the particular area. The resultant different images were suitably color-coded highlighting the changes under signification, moderate and marginal categories. Normalized difference vegetation index(NDVI) has been computed using the infrared and red bands of the satellite data. The rationing is done to remove temporally or spatially varying gain and bias factor, suppressing radiance variations arising from topographic slope and aspect and enhances radiance different between soils and vegetation.

\section{2) Data of population:}

Table: 1 Following is the classification of population of Balesar block

\begin{tabular}{|c|c|c|c|c|c|c|}
\hline $\begin{array}{c}\text { B.P.L. } \\
\text { family }\end{array}$ & $\begin{array}{c}\text { landless } \\
\text { family }\end{array}$ & $\begin{array}{c}\text { Small } \\
\text { farmer }\end{array}$ & $\begin{array}{c}\text { Marginal } \\
\text { farmer }\end{array}$ & $\begin{array}{c}\text { Family } \\
\text { of ST }\end{array}$ & $\begin{array}{c}\text { Family } \\
\text { of SC }\end{array}$ & $\begin{array}{c}\text { Total } \\
\text { of } \\
\text { family }\end{array}$ \\
\hline 273 & 368 & 232 & 283 & 83 & 226 & 1465 \\
\hline
\end{tabular}

\section{3) Parameters of study area:}

Parameters
Land use and land cover
Slope map
Contour map
Drainage map
Rainfall water
Runoff water
Water requirement

Symbols
LULC
SM
CM
DM
RW
RW
WR

Table 2. Data used for analysis of watershed management: The data will be collected as per the following table and analyzed using ARC GIS tools.

\begin{tabular}{|c|c|c|}
\hline Sensor/Data & Categories & Source \\
\hline \multirow{4}{*}{$\begin{array}{c}\text { Ground based } \\
\text { observations }\end{array}$} & $\begin{array}{c}\text { Data of } \\
\text { Agriculture }\end{array}$ & $\begin{array}{c}\text { Agri. Dept of } \\
\text { Jodhpur }\end{array}$ \\
\cline { 2 - 3 } & $\begin{array}{c}\text { Data of } \\
\text { Population }\end{array}$ & Census 2011 \\
\cline { 2 - 3 } & $\begin{array}{c}\text { Data of Runoff } \\
\text { water }\end{array}$ & $\begin{array}{c}\text { WSCDC, } \\
\text { Jodhpur }\end{array}$ \\
\cline { 2 - 3 } & Data of Rainfall & IMD grid data \\
\hline \multirow{2}{*}{$\begin{array}{c}\text { IRS P6- } \\
\text { LISS-III } \\
\&\end{array}$} & LULC & ISRO \\
\cline { 2 - 3 } & Road & ISRO \\
\cline { 2 - 3 } & Khasra number & ISRO \\
\hline
\end{tabular}




\begin{tabular}{|c|c|c|}
\hline RESOURCE & Contour & ISRO \\
\cline { 2 - 3 } SAT-LISS-III & Soil type & ISRO \\
\hline SRTM90 M & $\begin{array}{l}\text { Slope and } \\
\text { Drainage }\end{array}$ & NASA \\
\hline
\end{tabular}

\section{4) Software's used:}

- $\quad$ ERDAS Imagine 9.1

- $\quad$ ARC GIS 10.1.1

- $\quad$ Microsoft office 2010

\section{5) Methodology:}

Methodology is developed for finding out the water deficit and water surplus in a watershed scale for the entire Panchayat samiti, Balaser block [Krishna Murthy 2004].

The satellite data (1:50,000 Scale) thus collected will be used to plot Geomorphology map, Soils map, Geology/structure map, Land use map which will provide the information on the flow status. The ground based information will be used in topographical maps like slope map, base map, watershed map, contour map. The information on flow status, combined with topographical maps (1:50,000 Scale) provides the drainage map using ARC GIS tools.

In the drainage map, we delineate 2 and 3 order streams. For this purpose, each segment of a stream or river within a river network is treated as a node in a tree, with the next segment downstream as its parent. When two first-order streams come together, they form a second-order stream. When two second-order streams come together, they form a third-order stream. Streams of lower order joining a higher order stream do not change the order of the higher stream. Thus, if a first-order stream joins a second-order stream, it remains a second-order stream. It is not until a second-order stream combines with another second-order stream that it becomes a third-order stream.

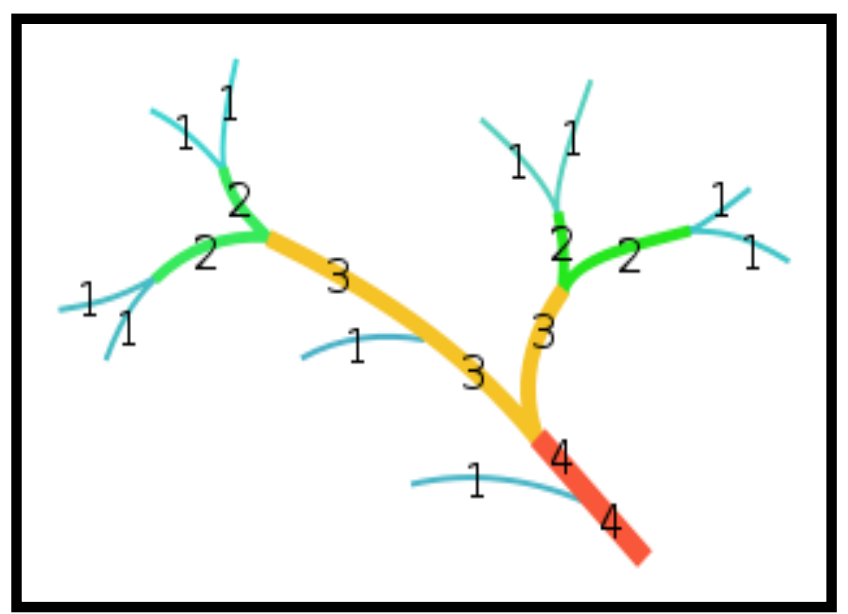

Figure: 1. Stream order

Further, we demarcate the immediate downstream area and overlay the drainage map over imagery and decide the site to be recommended for water harvesting.
Watershed management is a prerequisite for efficient and sustainable water resource management. The watershed management is given flow chart.

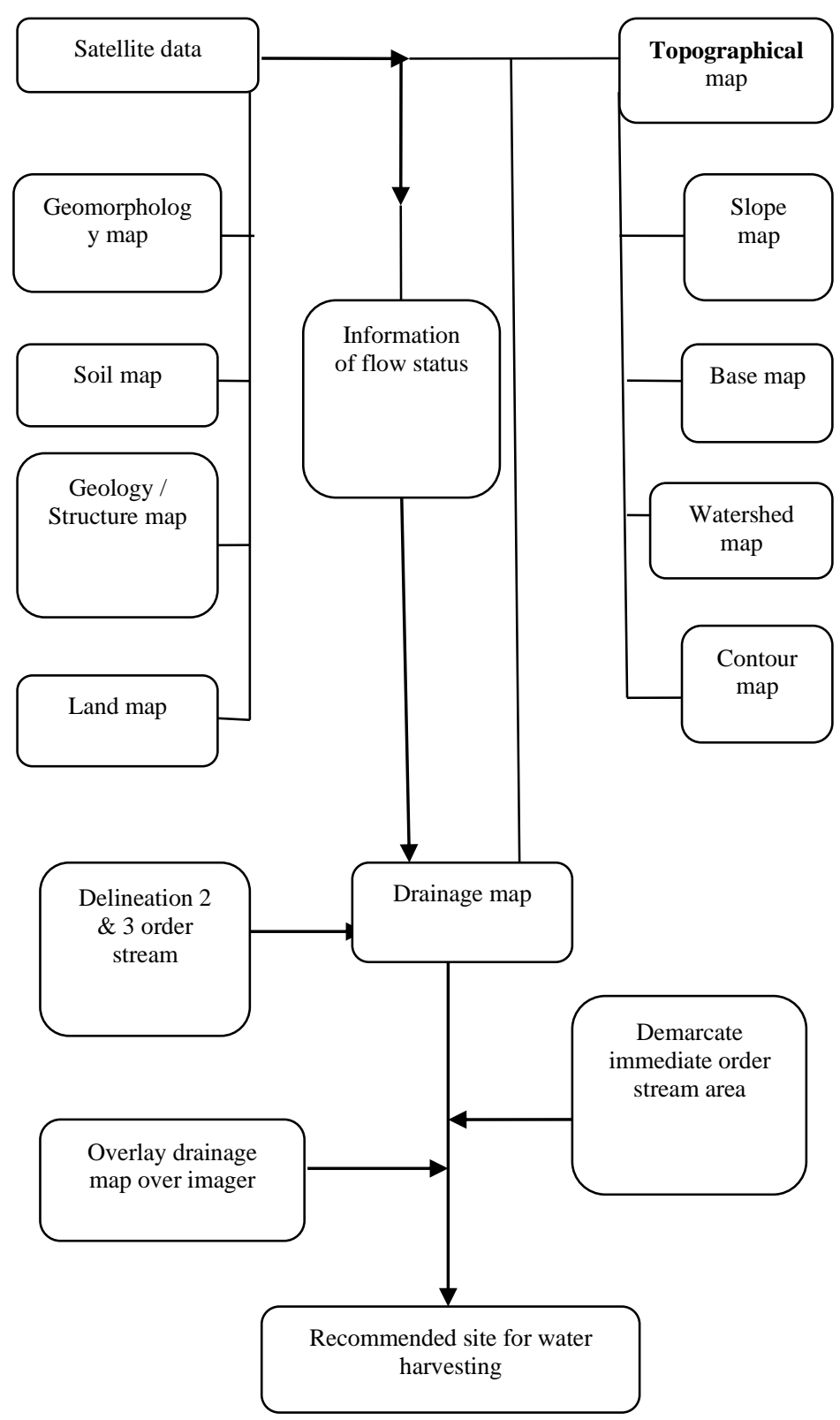

Figure 2. Flow design for optimum watershed management

\section{IV.ESTIMATION OF COMPONENTS}

\section{1) Khasra map:}

Khasra map gives unique ID number to lands of farmers of Kuijodha, Kuiindha, Ketuhema and Belwa villages, through this map one can identify their lands quickly. 


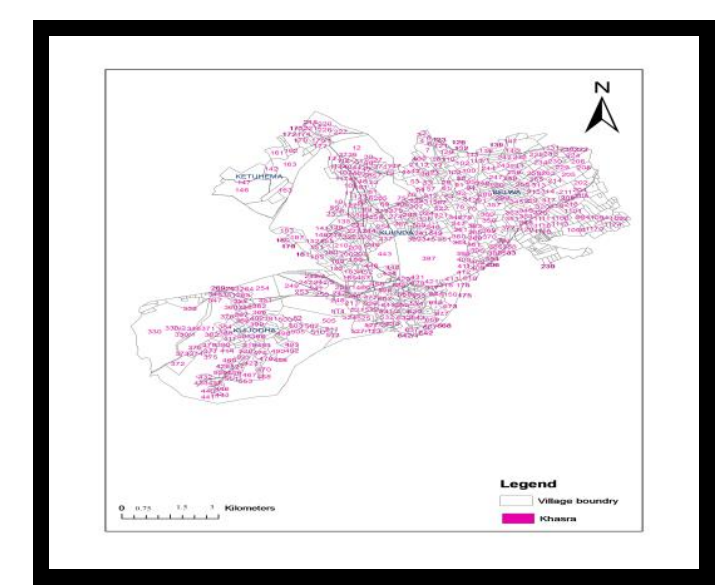

Figure 1. Khasra map of villages in Balesar block (Jodhpur)

\section{2) Road map:}

The Balesar Block content district roads, metalled road, National highway, unmettalled road, etc. It is connected with Jodhpur and Rajasthan. Roads provide suitable facility for transportation.

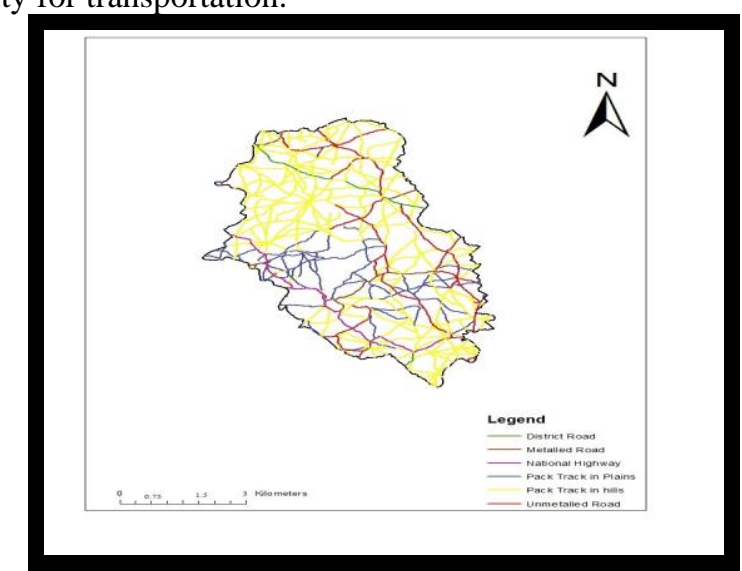

Figure 2. Road map of villages in Balesar block (Jodhpur)

\section{3) Soil map:}

Soil map of study area is shown in Figure 4.3. Soils of the study area have been classified in to three classes: coarse soil (Ketuhema), loamy soil (Kuijodha, Kuiindha, Ketuhema and Belwa) and sandy soil are found in Kuijodha, Ketuhema and Kuiindha. Most of the area was under coarse soil classes followed by loamy and sandy soil.

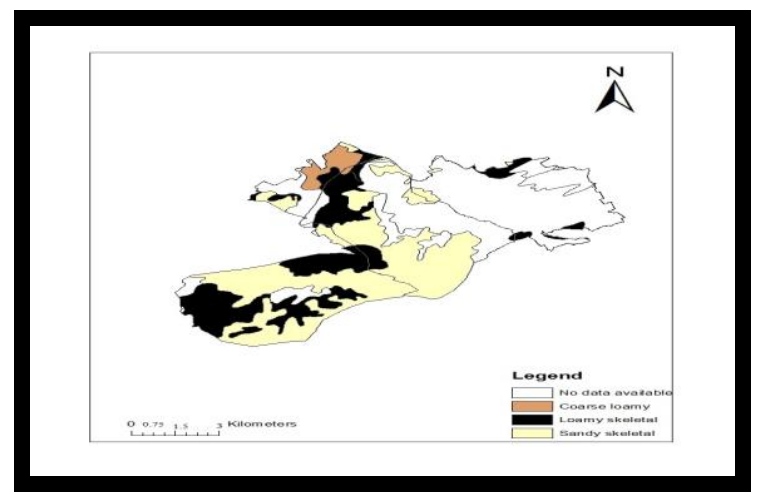

Figure 3. Soil map of villages in Balesar block (Jodhpur)

\section{4) Slope map:}

The slope of the site contributes to runoff. The more the ground slopes, the more water will runoff from the site. Steep slopes can cause water to run off at a rapid rate. This is particularly the case where water percolation into the soil is slow (on naturally slowly draining soil or where there is poor soil structure or both). Highest risk fields are those greater than 35 percent. Fields with gentle slopes less than 0-1 percent are at lower risk to rapid runoff and erosion. But water can still run and gather momentum on gentle slopes, particularly where the slope is long and infiltration rate is slow. Where the ground is level, water will tend to pond.

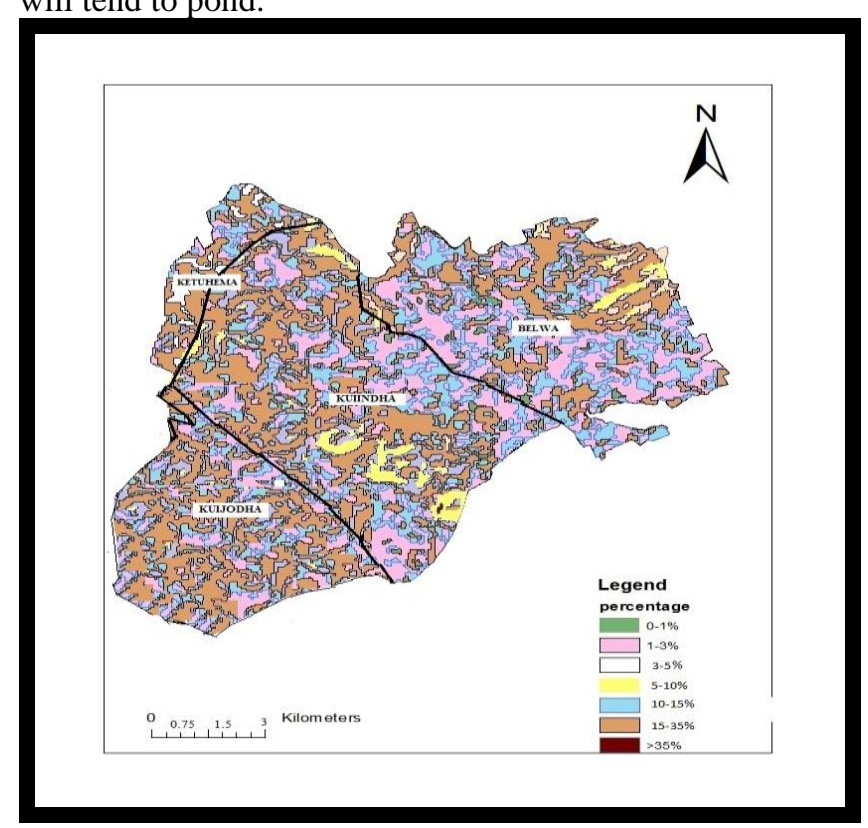

Figure 4. Slope map of villages in Balesar block (Jodhpur)

\section{5) Contour map:}

A contour map on which the shape of the land surface is shown by contour lines, the relative spacing of the lines indicating the relative slope of the surface. A map that shows elevations above sea level and surface feature of the land by means of contour lines. Crops are growing according to contour line in case protect the land from soil erosion.

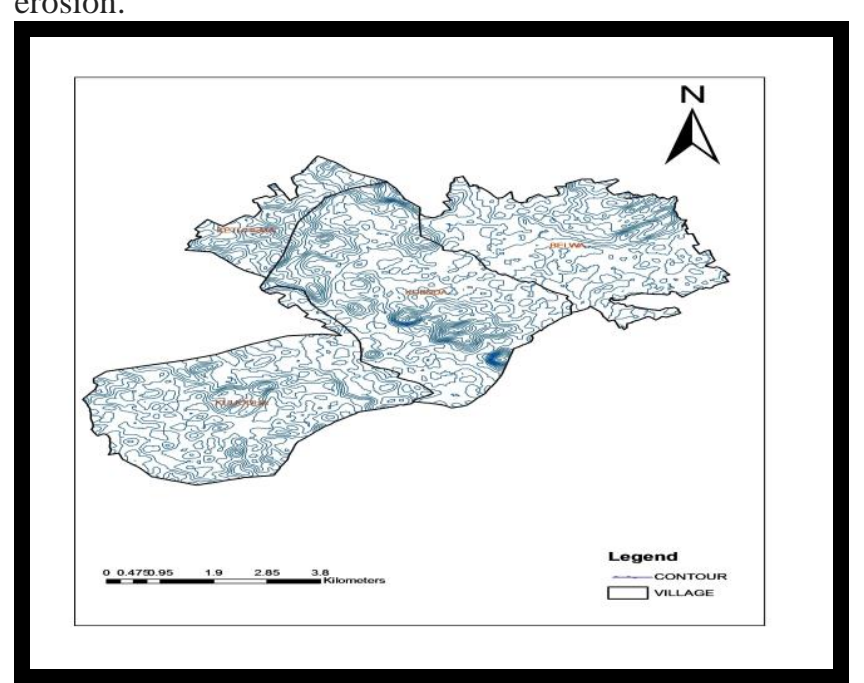

Figure 5. Contour map of villages in Balesar block (Jodhpur) 


\section{RESULTS AND DISCUSSION}

A project report was conducted on watershed management for Balesr Block, Distt. Jodhpur (Raj). Data rainfall year (2010 to14), runoff water year 2015 and data of lulc, drainage. The results obtain in present investigation have been presented in this chapter. The results are presented under the followings:

\section{1) LULC map:}

Land use and land cover map of study area (3,840 ha) generated from IRS P6 -LISS-III data for the year 2015 is shown in Figure 5.1.

Most of the area comes under agricultural land whereas East part of agriculture (2,050 ha) with three seasonal crops Kharif, Rabi, summer.

North part are sandy soil (400 ha), south part of land with scrubs (75 ha), land without scrubs (700 ha).

West part are covered by Barren rocky/stone (121 ha), sandy soil (400 ha), settlement (215 ha), river (200 ha) and water body (120 ha) area. Our observations are similar to Das et al. (2013) at work in Tinsukia district of Assam (India).

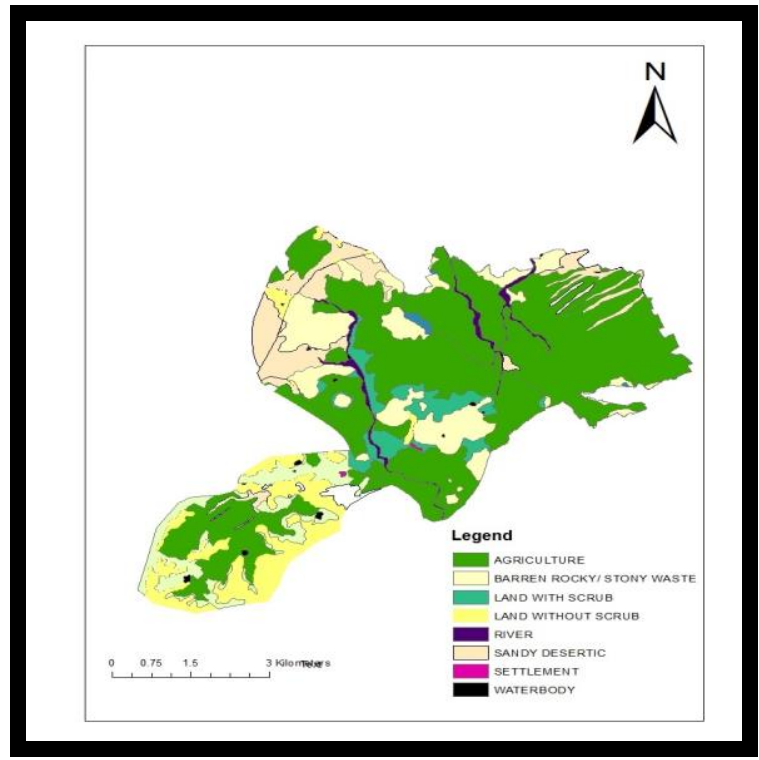

Figure 5.1: LULC map of villages in Balesar block (Jodhpur)

\section{2) Drainage map:}

SRTM DEM $90 \mathrm{~m}$ data was used for the generation of drainage, river and water body by using hydrological tools in Arc GIS. In the map most of drainage Kuiindha after Kuijodha village and river are found in Belwa and Kuijodha. A suitable threshold value was assumed to derive the drainage network and it is to be used in delineation of the sub watersheds. Drains give the nature of surface slope and their spatial arrangement provides the idea about runoff analysis. Figure 5.2 below shows the potential drainage, water body and river of study area. The present investigation is similar to the investigation done by supported by Ali and Ali (2014) at work in catchment, Kashmir Valley, India. They reported that drainage network along with their order was extracted from survey of India toposheets (1: 50,000 scale).

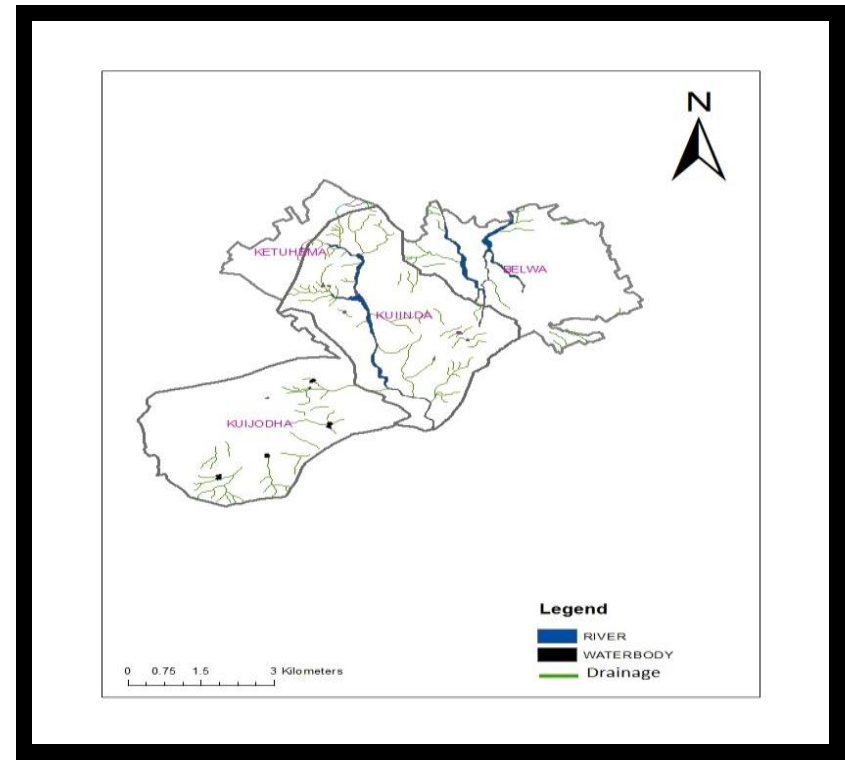

Figure 2. Drainage map of villages in Balesar block (Jodhpur)

\section{3) Rainfall:}

In the study area the monsoon season takes place between months of June to August. Average annual rainfall $(486.66 \mathrm{~mm})$ of the sub basin, in 2010 receives the highest rainfall up to $676.5 \mathrm{~mm}$ whereas 2012 was the drought year so least amount of rainfall was received up to 279.5 $\mathrm{mm}$. From the data of rainfall year 2010-14, while the highest rainfall took place in $2010(676.5 \mathrm{~mm})$ average annual rainfall was $486.66 \mathrm{~mm}$.

Table 1. Annual rainfall year 2010 to 2014 of the study

\begin{tabular}{|c|c|c|c|c|c|}
\hline \multicolumn{7}{|c|}{ area } \\
\hline YEAR & 2010 & 2011 & 2012 & 2013 & 2014 \\
\hline Rainfall & 676.5 & 566 & 279.5 & 300 & 611.3 \\
\hline
\end{tabular}

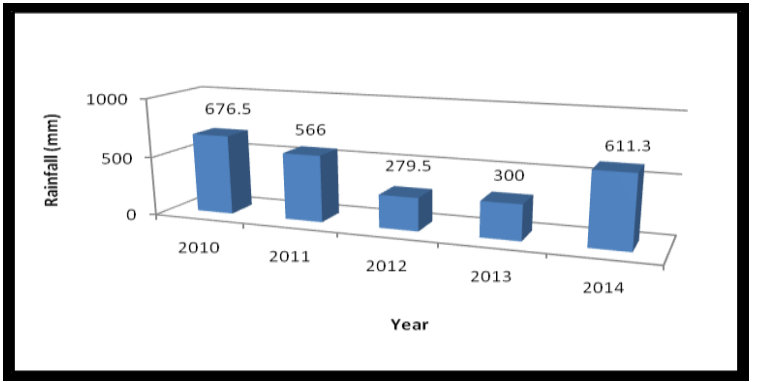

Figure 3. Annual rainfall year 2010 to 2014 of the study area

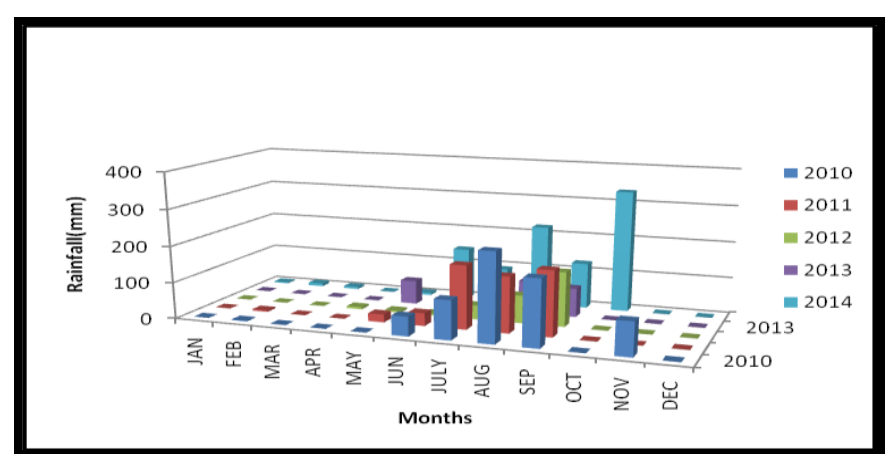

Figure 4. Monthly variation of rainfall year 2010 to 2014 of the study area 


\section{4) Daily variation of rainfall year 2010 to 2014 :}

To understand the spatial watershed distribution, we need to analyze the distribution of rainfall and surface runoff which occur in a basin. The highest rainfall is received in the month of July and August and least rainfall is received in month of September, October and February. It is observed that the south-east part of the basin receives maximum amount of rainfall. The western part of the basin receives least amount of rainfall. Monthly variation of rainfall is shown in figure16 to 20.The present investigation is supported by study of Luni basin at Jodhpur by Lodha et al. (2013). They analyzed avarege monthly rainfall for 2001-2004 and found that highest rainfall is received in the months of July and August.
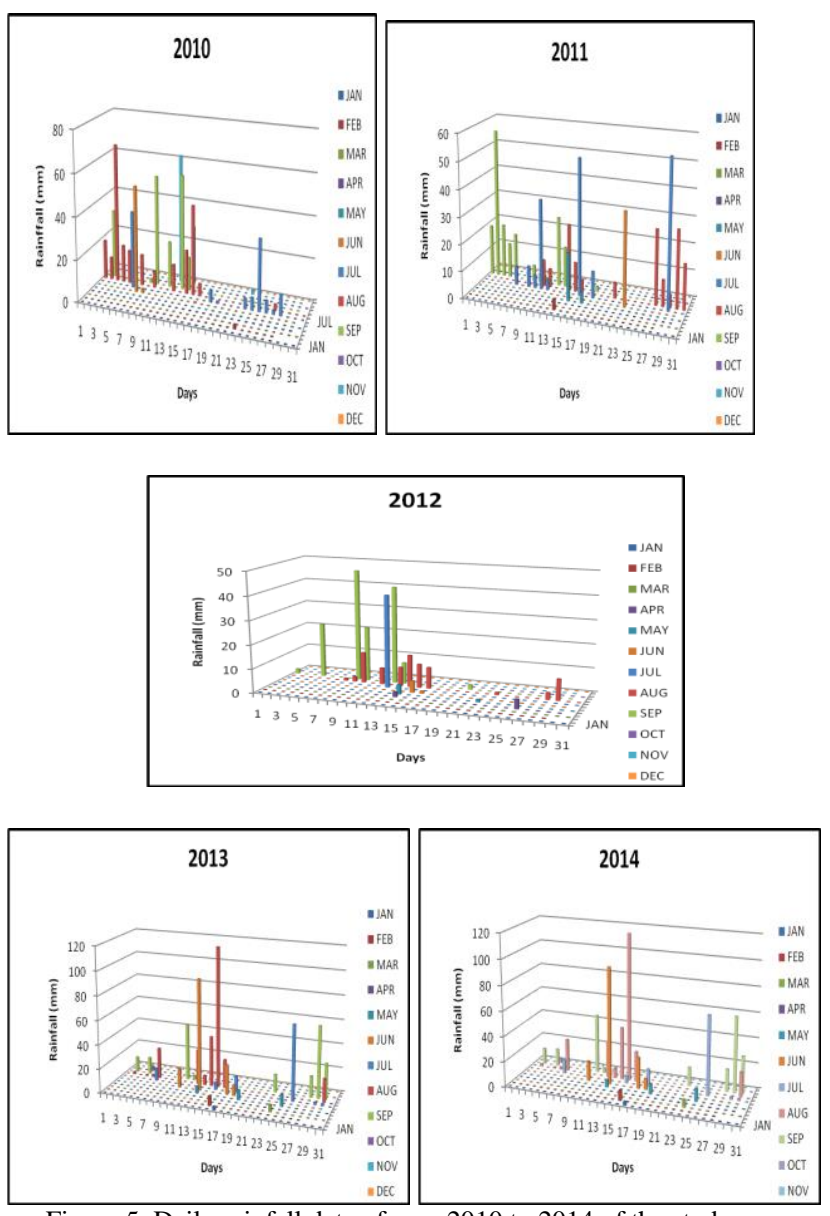

Figure 5. Daily rainfall data of year 2010 to 2014 of the study area

\section{5) Agriculture data:}

The villages of Balesar Block under study grown two seasonal crops Kharif and Rabi of year 2015. The Kharif crops mostly grown are Guar, Mung, Mot, Pearl millet, Sorghum and Rice followed by Rabi crops Wheat, Mustrad, Cummin and Isbgol. The total production of kharif crops in as per the Tables 5.2 and 5.3.
Table 2. Kharif crops of study area

\begin{tabular}{|c|c|c|c|c|c|}
\hline Killages & Kui & $\begin{array}{c}\text { Kui } \\
\text { jodha }\end{array}$ & Belwa & $\begin{array}{c}\text { Ketu } \\
\text { hema }\end{array}$ & $\begin{array}{c}\text { Production } \\
\text { (kg/ha) }\end{array}$ \\
\hline Guar & 345 & 577 & 121 & 121 & 3700 \\
\hline Mot & 100 & 411 & 94 & 47 & 300 \\
\hline $\begin{array}{c}\text { Pearl } \\
\text { millet }\end{array}$ & 74 & 118 & 114 & 57 & 1000 \\
\hline Mung & 31 & 39 & 34 & 17 & 500 \\
\hline Sorghum & 5 & 4 & 0 & 0 & 700 \\
\hline Rice & 4 & 5 & 0 & 0 & 1200 \\
\hline
\end{tabular}

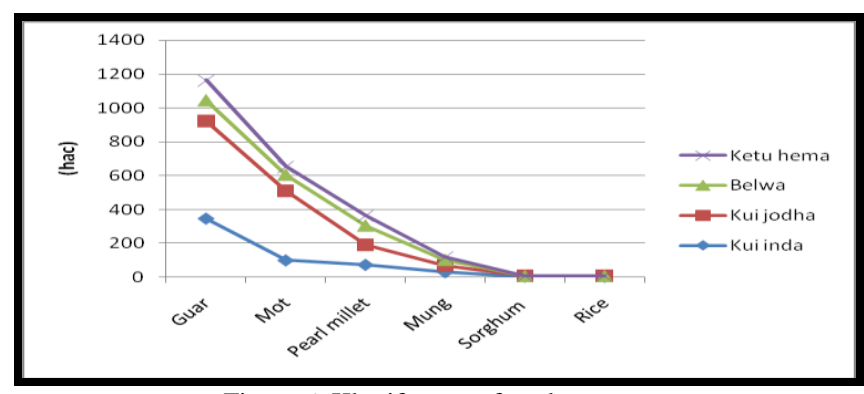

Figure 6. Kharif crops of study area

Table 3.Rabi crop of study area.

\begin{tabular}{|l|c|c|c|c|c|}
\hline Crops & $\begin{array}{c}\text { Kui } \\
\text { inda }\end{array}$ & $\begin{array}{c}\text { Kui } \\
\text { jodha }\end{array}$ & Belwa & $\begin{array}{c}\text { Ketu } \\
\text { hema }\end{array}$ & $\begin{array}{c}\text { Production } \\
\text { (kg/ha) }\end{array}$ \\
\hline Wheat & 60 & 50 & 46 & 60 & 2000 \\
\hline Mustrad & 39 & 39 & 29 & 60 & 1500 \\
\hline Cummin & 39 & 28 & 4 & 36 & 600 \\
\hline Isbgol & 24 & 36 & 13 & 32 & 600 \\
\hline
\end{tabular}

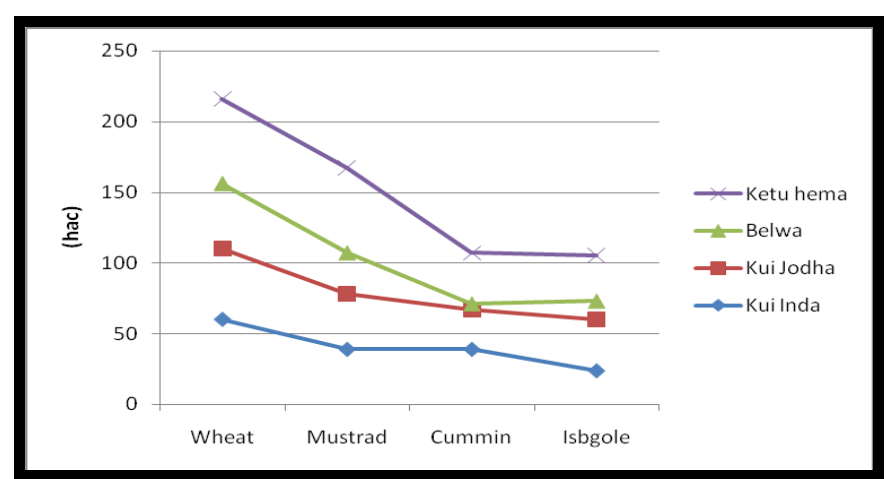

Figure 7. Rabi crops of the study area

\section{6) Watershed management for Balesar block year (2015):}

It was observed that 2997.4 TCM/year amount of total runoff water is available but storage of runoff water is (2544.01 TCM) by water harvesting Tanks, Ponds, Anicuts, Check dam etc. and where as maximum water requirement in the present scenario is (animals, humans 1710.42 TCM) and agriculture (2807 TCM). Increase in future demands with respective to crop production area (3370.5 TCM) this additional requirement of water to be fulfill by ground water (2292 TCM). Then the requirement of water is to be fulfilled completely (1080 TCM). Similar work was done by Saharkar et al. (2015) for their study of Telagana (India) and Kaburi and Odera (2016) also worked on watershed conservation and management of the upper Gucha watershed (Kenya). These reported that water harvesting be done by ditch, 
furrows, recharge basins, bench terracing, contour bunds, gully plugs, nalah bunds, check dams and percolation ponds.

Table 4. Total runoff water in Balesar block:

\begin{tabular}{|c|c|c|}
\hline $\begin{array}{c}\text { Sr. } \\
\text { No. }\end{array}$ & Level runoff water & $\begin{array}{c}\text { Quantity of } \\
\text { water(TCM) }\end{array}$ \\
\hline 1 & High & 1128.48 \\
\hline 2 & Medium & 1169.34 \\
\hline 3 & low & 400.58 \\
\hline & Total & 2944.4 \\
\hline
\end{tabular}

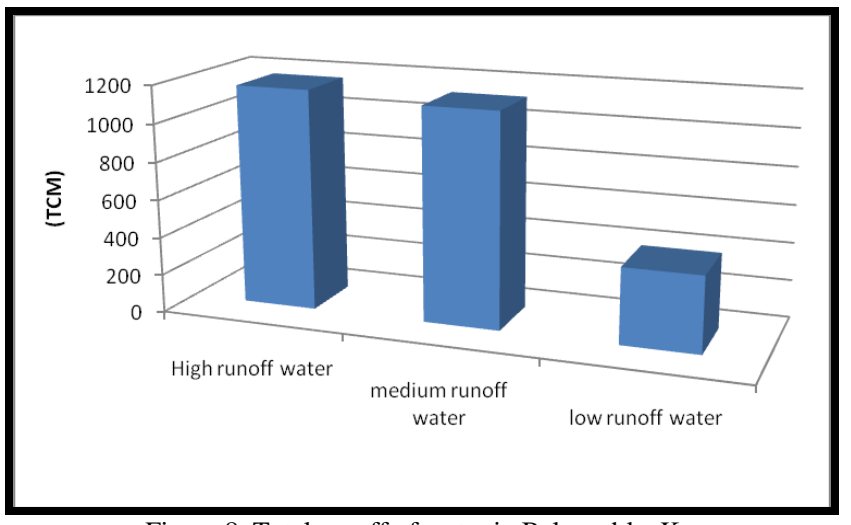

Figure 8. Total runoff of water in Balesar blocK

Table 5. Storage of runoff water in Balesar block:

\begin{tabular}{|c|c|c|c|}
\hline $\begin{array}{c}\text { Sr. } \\
\text { No. }\end{array}$ & $\begin{array}{c}\text { Water harvesting } \\
\text { through }\end{array}$ & $\begin{array}{c}\text { Capacity } \\
\text { (TCM) }\end{array}$ & Numbers \\
\hline 1 & Anicuts & 1136 & 2 \\
\hline 3 & Ponds & 1020.2 & 286 \\
\hline 4 & M.P.T. & 236 & 23 \\
\hline 5 & Tanks & 128.21 & 30 \\
\hline 6 & Any & 33.6 & 21 \\
\hline & Total & 2544.01 & 349 \\
\hline
\end{tabular}

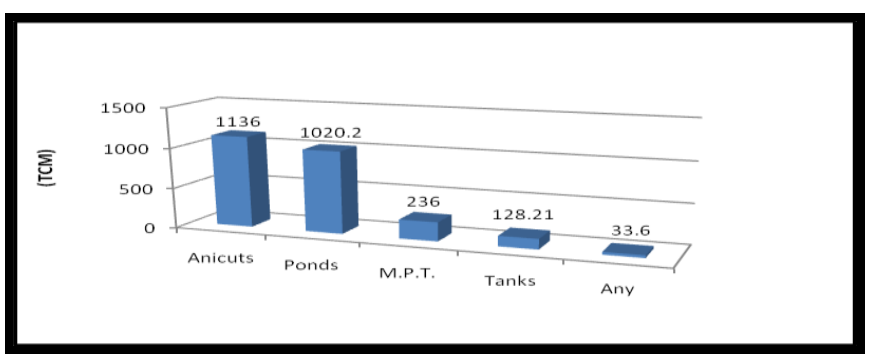

Figure 9. Storage of runoff water by harvesting

Table 6. Water requirement for humans and animals (TCM):

\begin{tabular}{|c|c|c|}
\hline Sr. No. & Name & Water requirement (TCM) \\
\hline 1 & Humans & 877.898 \\
\hline 2 & Animals & 832.528 \\
\hline & Total & 1710.426 \\
\hline
\end{tabular}

Table 7. Water requirement for crops (TCM):

\begin{tabular}{|c|c|c|c|c|c|}
\hline $\begin{array}{c}\text { Sr. } \\
\text { No. }\end{array}$ & $\begin{array}{c}\text { Name of } \\
\text { crops }\end{array}$ & $\begin{array}{c}\text { Requirement } \\
\text { for the year } \\
2015\end{array}$ & $\begin{array}{c}\text { Expected } \\
\text { future } \\
\text { requirement } \\
\text { (A) }\end{array}$ & $\begin{array}{c}\text { Requirement } \\
\text { to be } \\
\text { fulfilled by } \\
\text { ground } \\
\text { water (B) }\end{array}$ & $\begin{array}{c}\text { Water } \\
\text { deficiency } \\
\text { (A-B) }\end{array}$ \\
\hline 1 & $\begin{array}{c}\text { Pearl } \\
\text { millet }\end{array}$ & 817.5 & 981.0 & 302.5 & 678.0 \\
\hline 2 & Wheat & 930.0 & 1116.0 & 930.0 & 186.0 \\
\hline 3 & Mustard & 417.5 & 417.5 & 83.5 & 1536.0 \\
\hline 4 & Cummin & 267.5 & 321.0 & 267.5 & 53.5 .0 \\
\hline 5 & Isbgol & 262.5 & 315.0 & 262.5 & 52.5 \\
\hline 6 & Ber & 2.5 & 7.5 & 2.5 & 5.0 \\
\hline & Total & 2807.5 & 3370.5 & 2292.2 & 1080.0 \\
\hline
\end{tabular}

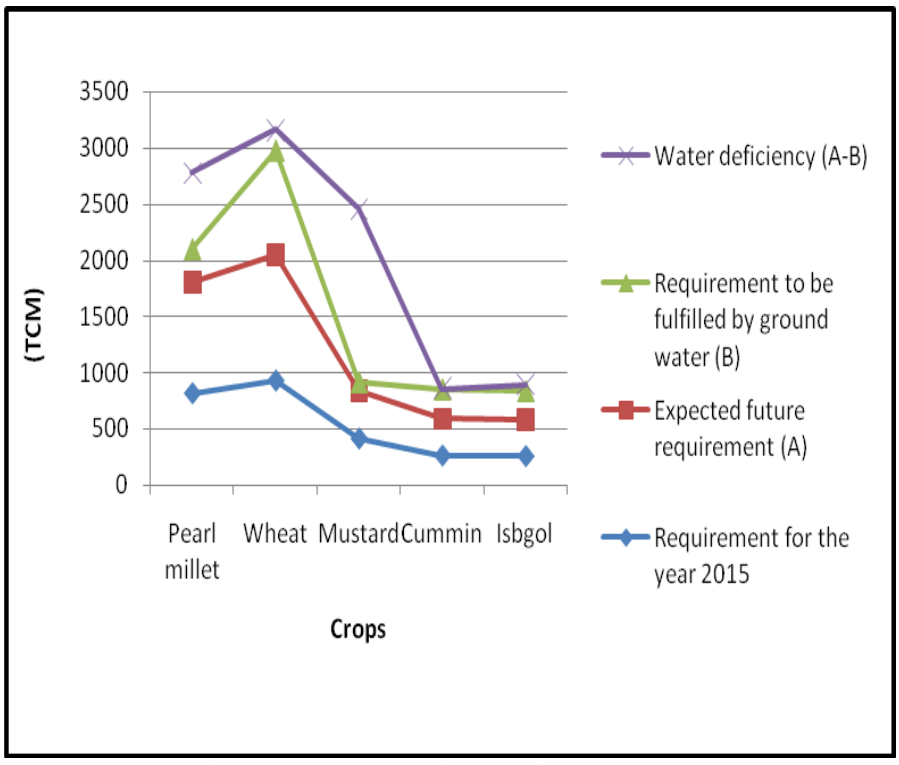

Figure 10. Water requirement for crops

\section{VI.SUMMARY AND CONCLUSION}

The study entitled "Watershed Management for Mukhyamantri Jal Sawablamban Abhiyan by Remote Sensing and GIS in the Panchayat Samiti Balesar block, Distt. Jodhpur (Raj)", was conducted. Following are summary and conclusion.

Khasra map, road map, soil map and slope map were prepared for the Balesar block based on the data of year.

The land use and land cover of Balesar Block have been studied for the year 2015, map has been prepared depicting the some.

Drainage map has been prepared that describes the nature of surface slope, thus providing idea of runoff water.

The rainfall data of period 2010-14 years depict that highest rainfall is received in the months of July, August and September and rainfall is least in the months of January to June, November and December.

The rainfall data together with storage capacity of available watershed, the runoff water and the requirement of water for animals, humans and agriculture has been studied. It was found that the total water storage capacity was 2544.01 TCM where as runoff was 2997.47 TCM. The total water required for animals and humans being 1710.42 TCM. The water required for agriculture in the year 2015 was 2807.0 TCM expected future requirement was 3370.5 TCM. The additional requirement may be 
fulfilled by the available 2292.0 TCM ground water but there will be need of 1080.0 TCM water.

\section{VII.CONCLUSION}

The average rainfall and runoff has been studied together with the present storage capacity and the present .as well as expected future requirement of water to suffice the need of humans, animals and agriculture for the Balesar block, Jodhpur.

As visible from the data discussed in the report. More water harvesting is required and for optimally storing the runoff waters several maps such as slope, contour and drainage etc. of the Balesar block have been prepared in this study. These maps should be taken care of while selecting any area for creating watershed for the purpose of water harvesting. Looking to the difference between amount of water actually available and future requirement of water, it is strongly recommended that more watersheds be prepared to secure runoff water.

\section{BIBLIOGRAPHY}

[1] Bhavani, R. 2013. Comparision of mean and weighted annual rainfall in Anantapuram district. International Journal of Innovative Research in Science, Engineering and Technology. Vol. 2, 2794-2795.

[2] Dania, N. 2012. Application of remotely sensed imagery to watershed analysis a case study of lake Qerous (Egupt). International Water Technology Journal Vol. 2, 48-49.

[3] Das, P.T., Das, R. and Sudhakar, S. 2013. Land use diversification plan for a cluster of village using geospatial technology. A case study in Tinsukia district of Assam (India). International Journal of Advancement in Remote Sensing, GIS and Geography, Vol.1, 25-33.

[4] Kaburi, A. N. and Odera, P. A. 2016. GIS and remote sensing support in watershed conservation and management. Case study of the upper Gucha watershed (Kenya). IOSR Journal of Environmental Science, Toxicology and Food Technology. Vol. 8, 35-36.

[5] Kiran, V.S.S. 2013. Change detection in land use and land cover using remote sensing \& GIS techniques. A case study of Mahananda catchment, Luca Marchese (West Bengal). International Journal of Research in Management Studies. Vol. 2 , 68-69.

[6] Krishna Murthy, Y. V. N 2004. Remote sensing and GIS application in watershed management. International conference in Indian space research organization, Banglor Publ, 65-71.

[7] Lodha, J., Joseph. M., Jeyaseelan A.T. and Sharma J. R. 2013. Water balance analysis for luni upper sub basin using Remote sensing and GIS. Indian cartographer Vol. 19, 108-109.

[8] Nagarajan, N. and Poongothai, S. 2011. Trend in land use and land cover change detection by remote sensing and GIS application. International Journal of Engineering and Technology. Vol.3, 264-265.

[9] Nicholson, S. E. and Selato, J. C. 2000. The influence of la Nina on African rainfall (India). International Journal of Climatology Vol.20 1761-1762.

[10] Ramaswamy, S. K. and Ranganathan, M. B. A. 2014. Land use and land cover classification using local multiple patterns from very high resolution satellite imagery. ISPRS Technical Commission VIII Symposium, Hyderabad, India. Vol. 3, 971.

[11] Robertson, A. W. and Moron, V. 2008. Seasonal predictability of daily rainfall statistics over Indramayu district (Indonesia). International Journal of Climatology. Vol. 2, 1-2

[12] Saharkar,U. R., Kulkarni, D. D. and Pore, A. A. 2015. Micro \& macro watershed management using remote sensing and GIS software for Talegana(India). International Journal of Engineering and Innovative Technology. Vol.4, 194-195.

[13] Schuurmans, J., Clemmens, A. J., Dijkstra, S., Hof, A. and Brouwer, R. 1999. Modeling of irrigation and drainage canals for controller design. Journal of Irrigation and Drainage Engineering Vol. 125, 189-190.

[14] Twumasi, Y. A. 2006. Management of watersheds with remote sensing and GIS. A case study of river Nigeria delta region (Nigeria). Annual conference Reno, Nevada. 1-2.

[15] Valipour, M. 2012. Effect of drainage parameters change on amount of drain discharge in subsurface drainage systems. Journal of Agriculture and Veterinary Science. Vol. 1, 10-12.

[16] Waghaye, A. M., Siddenki, V. and Kumari, N. 2015. Design rainfall estimation using probabilistic approach for Adilabad district of Telangana (India). International Journal of Advanced Scientific and Technical Research Issue Vol. 5, 301-302.

[17] Yesodha, L., Meenambal, T. and Manikandan, K. R. 2015. Design of storm water drainage system to enhance ground water level. A case study on hosur inner ring road. International Journal of Industrial Engineering and Management Science, Vol. $5,100-102$

\section{AUTHOR BIOGRAPHY}

${ }^{[1]}$ Mr Vinod Kumar Gusaiwal (Research Scholar),M. Sc. ICT (Agriculture), Department of Statistics, Mathematics and Computer Science, S.K.N. College of Agriculture, Sri Karan Narendra Agriculture University, Jobner.

${ }^{[2]}$ Dr Pratibha Manohar, Asitt. Professor, (Mathematics), Department of Statistics, Mathematics and Computer Science, S.K.N. College of Agriculture, Sri Karan Narendra Agriculture University, Jobner.

${ }^{[3]}$ Mr Suparn Pathak (Scientist 'SSF'), Department of Reginal Remote Sensing Centre ,RRC-WEST,NRSC, ISRO,Jodhpur. 